DOI https://doi.org/10.32837/app.v0i64.191

УДК 17.022.1:32.019.51

Милосердна I. М.* (НУ «ОЮА»)

ORCID ID: https://orcid.org/0000-0003-2083-9500

\title{
ІМІДЖ ПОЛІТИЧНОГО ЛІДЕРА ЯК КАТЕГОРІЯ РR-ТЕХНОЛОГІЇ
}

\section{IMAGE OF THE POLITICAL LEADER AS A CATEGORY OF PR-TECHNOLOGY}

*Iryna Myloserdna - PhD in Political Science, Associate Professor at the Political Theories Department, National University «Odesa Law Academy» (23, Fontanska Doroha St., Odesa, Ukraine).

\section{Abstract}

The article is devoted to a comprehensive study of the image of a political leader as a category of PR technology. It is argued that, in practical political science, image is, first and foremost, a generalized perception that is shared by ordinary citizens about political subjects. Another thing is that it is purposefully shaped by image-makers. The article identifies and analyzes the following basic approaches to defining the notion of a political leader's image: ontological, anthropological, value and ethical. It has also been found that, for contemporary politics, an interesting fact is that among the personal characteristics the role of the leader's business and moral qualities has recently increased. Among them, intellectual qualities (which are often equated with education) are the most important. Further, in terms of frequency, honesty is a policy, although voters do not demand absolute honesty from it. In addition, the leader must also be kind and human, loyal to the people. An ideal politician must be proficient in public speaking and be «accessible to talk to ordinary people». The article also notes that a political leader often tries to gain power through manipulation technologies. It is established that manipulation technologies do not remain inadvertent since numerous studies of electoral behavior prove that the majority of electorates are subject to suggestion, have a tendency to be influenced by the hypnotic action of belief in the miraculous capabilities of political forces. In the article, it is stated that in the Ukrainian politicum, image-makers often use the so-called «black» and "gray» $P R$ to reduce the image of a competitor. And among the methods used are the following: "valve», "live target», «drops», «tips», «resonance technology». 
Keywords: image, political leader, PR, political technologies, political manipulation.

Постановка проблеми. У політиці імідж поєднує в суспільній свідомості систему сприйняття політичної організації і політичного лідеpa, а також увесь комплекс вражень, оцінок, почуттів, зафіксованих як в програмних документах, заявах, виступах і управлінських рішеннях. Та частина політичної дії, яка отримує відображення в 3MI, може бути основою для створення суб'єктивного образу у свідомості виборців. В сучасній політичній науці фахівці з іміджелогії прагнуть визначити сутність іміджу, як соціально-політичного явища, але серед них немає повної єдності щодо дослідження феномену. Тим самим таке становище дає змогу говорити про актульність проблеми дослідження.

Метою статті $є$ комплексний аналіз сутності поняття «імідж» політичного лідера та його особливості як категорії PR-технології.

Аналіз основних досліджень та публікацій дає можливість стверджувати, що в сучасній науці існує значна кількість робіт, які присвячені вивченню феномену іміджу політичного лідера. Так, В. Королько вважає імідж «штучною імітацією або піднесенням зовнішньої форми якогось об'єкта і, особливо, особи» (Королько, 2002 , с. 294). К. Сгорова-Гантман називає іміджем «спеціально створюваний, навмисно формований політичний образ для досягнення поставлених цілей» (Егорова-Гантман, Плешаков, Байбакова, 2002, с. 5), а також «образ конкретного об'єкта, який існує в масовій свідомості» (Егорова-Гантман, 1994, с. 20). Можна зауважити, що на таке формулювання вплинуло первинне значення поняття «імідж», що походить від латинського «імаго», пов'язаного зі словом «imitary», що означає «імітувати».

Однак, деякими вченими пропонуються й інші, універсальні визначення. «Політичний імідж, - вважають, зокрема, російські науковці, - це сукупність уявлень, сприйнять і переконань, що має індивід або група індивідів про різні політичні явища або товари» (Пушкарева, 2002, с. 84). Як правило, поняття іміджу відноситься до конкретної людини, але може розповсюджуватися на групу осіб, організацію, товар. Він формується, як на основі реальної поведінки особи, так і під впливом оцінок інших (Бебик, 1996, с. 461).

Посилаючись на ці та інші визначення, можна відзначити, що в практичній політології імідж - це, насамперед, узагальнений образ, що складається у пересічних громадян про політичні 
суб'єкти. Інша справа, що нині його цілеспрямовано формують іміджмейкери. Можна погодитись і з визначенням, яке запропоноване В.О. Корнієнко та С.Г. Денисюком : імідж (від англійського «image») - це образ ідеального та реального політичного діяча, який сформувався в суспільній свідомості.

Слід зазначити, що це поняття найбільш вдало розкривається в політологічному словнику: «Політичний імідж - це своєрідне уявлення населення про ідеальне втілення тієї чи іншої соціальної ролі. Імідж політика включає такі характеристики: особистісні якості, організаторські, управлінські здібності (компетентність, вміння вести полеміку, участь у процесах прийняття рішень); характеристики, що зближують лідера з електоратом (пересічне походження, простота) тощо (Політологічний енциклопедичний словник, 2004, с. 228-230).

Таким чином, сутнісне поняття «іміджу» є складним соціальнопсихологічним феноменом, який створюється на грунті надто специфічного сплетіння інформаційних, емоційно-комунікативних і діяльнісних чинників. Як справедливо зазначає Г. Почепцов, імідж це готові інтерпретації світу, які дає нам сам світ. І ми активно користуємося ними. Утрируваний світ, репрезентований в іміджі, легше піддається розумінню, і ми спираємось на готові іміджеві схеми, коли інтерпретуємо нову реальність. Уявні світи мають також національний характер тому, що залежать від певного менталітету, культури населення (Почепцов, 1997, с. 11).

Перш ніж здійснювати розглядати особливості використання технологій при формуванні іміджу лідера необхідно звернути увагу на аналізі підходів до визначення сутності феномену іміджі.

В сучасній політології можна виокремити такі основні підходи до визначення поняття іміджу політичного лідера: онтологічний, антропологічний, ціннісний та етичний, де останній нас цікавить більшою мірою.

Представники онтологічного підходу (С. Голдмен, В. Бебик, Л. Невзлін), по-перше, вважають, що політичний імідж далеко не завжди повністю й адекватно відображає реальний об'єкт; по-друге, що він обов' язково повинен містити ознаки, за якими певний об'єкт ідентифікується і, відповідно, виокремлюється серед подібних; потретє, що він володіє значною стійкістю і силою інерції; нарешті, по-четверте, що політичний імідж активно добудовується самими реципієнтами відповідно до їх власних психологічних особливостей. На нашу думку, такий підхід хоча й досить повно висвітлює 
суть іміджу політика, однак коло проблем тут надзвичайно широке і включає в поле зору дослідників крім політичного іміджу безліч інших феноменів свідомості таких, як стереотипи, настанови, забобони, ціннісні орієнтації. Таким є визначення за О. Лавренко: «Імідж можна визначити як більш чи менш адекватний реальному суб'єктові образ особистості, який складається в масовій свідомості на свідомому і підсвідомому рівнях» (Лавренко, 2005, с. 24-25).

Представники антропологічного підходу (К. ЄгороваГантман, Дж. Скотт, П. Бірд, Е. Семпсон, Г. Почепцов, П. Гуревич, В. Шепель, Л. Браун, С. Блажнов, Б. Красовський, І. Криксунова, Т. Чередниченко) імідж політика співвідносять з різними персоніфікованими категоріями, наприклад, 3 такими, як «самопрезентація», «самопред'явлення», «управління враженням» тощо. На нашу думку, тут акцентується увага на рольовому характері іміджу, який виявляється, як публічне «Я» людини, як своєрідна маска, що застосовується для отримання привабливого вигляду в очах інших людей. Роль іміджмейкерів, які працюють над створенням особистісного образу, зводиться лише до опрацювання зовнішнього вигляду замовника, його тренінгу вербальної і невербальної поведінки. Антропологічне трактування політичного іміджу фіксує важливі специфічні властивості персоніфікованих об'єктів політичного світу і звужує це поняття межами властивостей, притаманних людині, що виключає з аналізу політичні інститути та ідеологічні конструкції. Слід відзначити, що такі науковці, як К. Єгорова-Гантман та Г. Почепцов досить переконливо доводять пріоритет образу політика під час сприйняття виборцями партії, але недостатню увагу приділяють дослідженню передвиборчого іміджу партії.

Представники ціннісного підходу (Б. Брюс, Ж. Сегела, О. Феофанов, I. Недяк, I. Терлецька, А. Цуладзе) акцентують увагу на штучному характері цього феномену. Практично не враховується те, що імідж - інтегрований феномен, який створює цілісний соціальний образ об'єкта. В рамках цього підходу акцентується увага на символічній сутності іміджу. Так, Ю. Сурмін і Д. Наріжний вважають, що імідж - це «певний символічний образ сприйняття якогось явища, об'єкта та людини», його формування «складає основний зміст політичної персоналізації політичного діяча» (Нарижный, Сурмин, 1999, с. 66).

У рамках ціннісного підходу під впливом різного роду PR-теорій було сформовано комунікативне розуміння іміджу. Так, Г. Почепцов 
вважає, що його можна тлумачити, як комунікативну одиницю, яка ідеально відповідає вимогам комунікативного простору (Почепцов, 1997, с. 35, 41). На його думку, імідж $є$ багатофакторним феноменом, оскільки, по-перше, вплив на людину здійснюється декількома каналами, по-друге, людина звикла оперувати багатошаровими структурами, кожна з яких може і опрацьовуватися окремо, і співіснувати у людському сприйнятті на своїй поличці. Але, з іншого боку, імідж не є багатофакторним феноменом, в пам'яті людини формується ніби цілісне уявлення, позитивно чи негативно забарвлене. Прикладом може слугувати визначення науковця М. Миліневського: «...образ, який сформований в масовій свідомості на основі наявних знань, досвіду сприймання візуальної інформації. Імідж створюється для того, щоб викликати бажані зміни в масовій свідомості і поведінці людей» (Миліневський, 1997, с. 340-342).

Що ж стосується етичного підходу, то його представники переконані, що іміджу політика притаманна певна моральна спрямованість, тому він розглядається як, свого роду, «друга натура», $з$ якою індивід оцінює себе i, яка за умови регулярного прояву, стає його справжньою сутністю. Проте в теоретичному аспекті складність полягає ще й у тому, що сутність іміджу представляється дещо розмитою на тлі різноманітних дисциплінарних наукових досліджень (філософські праці Аристотеля, Платона, Н. Макіавеллі, психологічні - 3. Фрейда, К.-Г. Юнга; соціологічні - I Бекешкіної, С. Головахи, Н. Паніної). Це, в свою чергу, також актуалізує необхідність системного дослідження сутності іміджу політичного лідера.

Враховуючи вищесказане, можна стверджувати, що імідж є комплексним поняттям, тому і аналізувати його можна, виходячи з різних перспектив. Ми зупинимося на трьох можливих підходах до іміджу: функціональному, при якому можна виділити різні його типи, виходячи з різного типу функціонування; контекстному, при якому ці типи ми знаходимо в різних контекстах реалізації; і зіставлювальному (порівняльному), при якому має місце порівняння близьких іміджів.

На думку В.О. Корнієнко в сучасній прикладній політології виділяється декілька можливих варіантів іміджу, які притаманні функціональному підходу: дзеркальний, поточний, бажаний, корпоративний і множинний.

Дзеркальний - це такий імідж, який властивий нашому уявленню про себе. Ми ніби дивимось у дзеркало і розмірковуємо, які ж ми. 
Зазвичай цей варіант іміджу позитивний, бо психологічно ми завжди ставимо на перше місце позитив. А його недолік - мінімальне врахування думок інших. Такий імідж може визначати характеристики як політичних лідерів, так і партій.

Поточний імідж створюється на основі сприйняття суб'єкта політики зовнішнім середовищем, виборцями, колегами, пресою. Саме в цій області знаходить своє застосування PR, оскільки недостатня інформованість, нерозуміння і упередженість формують імідж політика або партії не менше, ніж реальні вчинки. Так, основним завданням тут є отримання не стільки сприятливого образу, скільки правильного, оптимального типу іміджу.

Бажаний - це такий тип іміджу, який відображає те, до чого ми прагнемо. Такий тип ми достатньо часто зустрічаємо в описах і самописах політичних партій і нових громадських рухів. Прихід нового обличчя в стару структуру також відразу пов'язується з їі новим бажаним іміджем.

Корпоративний - це імідж організації в цілому, а не окремих підрозділів або результатів ії роботи. Тут і репутація організації, i iii успіх, і ступінь стабільності. Особливо важливим цей тип іміджу є для фінансових структур. Ця сфера повинна цікавити тих, хто працює в області PR. Для України цікавим варіантом такого іміджу є негативний образ Верховної Ради і його протиставлення Президенту.

Множинний - це імідж, який створюють під час об'єднання відомих політиків, політичних партій, громадських організацій у передвиборчий блок чи політичне об'єднання. Активно закріплюється єдиний імідж при проведенні партійних з'їздів.

Контекстний характеризується сприянням впровадженню або функціонуванню іміджу в контексті його використання в тій чи іншій сфері, орієнтується на певні верстви населення, рівні суспільної свідомості тощо.

Так, політик може мати неоднаковий імідж серед виборців та колег-депутатів, може користуватись популярністю серед однопартійців й мати негативний імідж у середовищі державних чиновників.

Відносно зіставлювального (порівняльного) імідж, то його можна визначити як підхід до формування іміджу, який полягає в порівнянні тих чи інших іміджевих характеристик. Таке зіставлення може відбуватися на рівні параметрів іміджу ідеального і реального політичного діяча, двох або більше лідерів, політичних партій. Кожен політик, політична партія прагнуть переконати громадян 
у володінні найбільшою кількістю позитивних рис, але далеко не всі сприймають цю інформацію так, як цього хотілося б політикам та їх іміджмейкерам.

Вітчизняні автори визначають в українській політичній практиці дещо інші, ніж на Заході, але ближчі нам типи політичних іміджів, що використовувалися кандидатами в народні депутати. Зокрема, В. Бебик пропонує таку їх класифікацію:

- «діловий імідж», який щонайкраще характеризується ідеологією: «ми заробили гроші для себе, заробимо їх і для вас»;

- «інтелектуальний імідж», що виник на основі твердження: для роботи в парламенті необхідні професіонали;

- «народний імідж» будувався на класичній популістській основі, на прагненні сформувати позитивне ставлення до себе як до «свого хлопця»;

- «політичний імідж» формувався на контрастному протиставленні соціалістів (формальних або прихованих) і націоналдемократів. В обох випадках ставка робилася на певні, добре відомі базові цінності основних політичних сил суспільства, а власне імідж створювався на декларуванні прихильності до цих цінностей, а не на основі особистісних характеристик кандидатів;

- «жіночий імідж» створювався на основі кредо: «Схоже на те, що чоловіки вже нічого не зможуть зробити. Обирайте жінок. Вони зроблять цей світ кращим»; імідж «місцевого жителя» будувався на основі постулату «Я - свій, я тут живу і нікуди не дінуся, тому що в мене тут родичі, сім'я...» (Бебик, 1996, с. 52-53).

Отже, аналізуючи імідж політичного лідера, його можна визначити, як набір якостей, які люди асоціюють з певною індивідуальністю. Імідж політика виникає на базі його вчинків або, використовуючи прийнятий в політології термін, подій. Так, подією стає висловлювання політиків стосовно тієї чи іншої проблеми, і образ породжуються саме із взаємин між полем преси і різними соціальними полями.

Але крім дослідження іміджу лідера як соціально-психологічного феномену, дане явище слід розглядати й з урахуванням його конструктивних параметрів.

У відомого фахівця П. Фролова ми зустрічаємо в структурі іміджу лідера, у змістовному плані, такі складові: а) особистісні риси політика; б) тип його політичної орієнтації; в) його місце в інститутах влади чи неформальних утвореннях (президент, парламентарій, кумир юрби) (Фролов, 2002, с. 169-182). 
Спеціаліст в галузі політичної психології Ю. Зущик детальніше аналізує конструктивні параметри іміджу і виділяє такі елементи: а) ідеологічний тип («політичне обличчя», «політичне забарвлення» тощо); б) особисті риси (реальні чи «награні»); в) соціальні ролі («соціальний статус», «соціальне походження»); г) «прізвисько», «псевдонім» лідера. Щодо функціонального зрізу, то він містить: мову (зокрема, лексикон); зовнішню атрибутику (одяг, зачіску, окуляри, автомобіль та ін.); міміку, пантоміміку, жестикуляцію та інші елементи невербальної поведінки (Зущик, 1999, с. 92-101).

Отже, можна зазначити, що в науковій літературі в структурі іміджу політичного лідера найчастіше виокремлюють три основні його складові:

1) персональні характеристики політика (фізичні, психофізіологічні особливості, характер, тип особистості, індивідуальний стиль прийняття рішень тощо); очевидно, що персональні характеристики різні у різних лідерів та мало піддаються змінам. Однак, завдяки тому, що спілкування лідера з прихильниками опосередковується 3MI, небажані персональні риси можуть і не потрапити їм на очі;

2) соціальні характеристики, під якими розуміємо статус лідера, не тільки пов'язаний з його офіційною позицією, а й з походженням, статками тощо. До соціальних характеристик відносимо також зв'язки лідера з соціальними групами, чиї інтереси він репрезентує та чиєю підтримкою користується, і з опонентами. Соціальна належність визначає норми і цінності, яких дотримується політик;

3) символічне навантаження: лідери стають символами певних ідеологій, певного політичного напрямку (Егорова-Гантман, 1994, с. 118; Современные тенденции развития символического пространства политики и концепт идеологии, 2004, с. 36), що пов'язано із стійкими культурними архетипами.

Можна погодитися 3 авторами колективної монографії «Аналітика. Експертиза. Прогнозування» відносно того, що імідж політика містить крім персональних і соціальних характеристик ще й таку групу, яка пов' язана з соціальними очікуваннями та можливими (оприлюдненими) пріоритетами дій політичного лідера у випадку отримання мандату, перемоги на виборах, що знаходить своє втілення у певній партійно-ідеологічній платформі, визначеному політичному курсі тощо (Макаренко, 2003, с. 115-116).

Цікавим фактом в сучасній політищі $є$ те, що якщо проаналізувати особистісні характеристики, то останнім часом зросла роль ділових і 
моральних якостей лідера. Серед них найсуттєвіше місце посідають інтелектуальні якості (які часто ототожнюють з освіченістю). Далі, за частотою згадувань, йде чесність політика, хоча виборці не вимагають від нього абсолютної чесності. До того ж, лідер повинен також бути добрим і людяним, відданим народу. Ідеальний політик повинен досконало володіти ораторським мистецтвом і бути «доступним для розмови із простими людьми». Крім того, на думку О. Вознесенської, виділяється енергійність, діловитість, відчуття актуальності, врівноваженість, серйозність і передбачуваність. На білыш віддаленому рівні знаходяться характеристики типу компетентності. Масова аудиторія не в змозі перевірити правильність характеристик цього рівня, тому вона задовольняється переносом компетентності з однієї посади на іншу.

Отже, імідж є феноменом, який не може бути розроблений достеменно в усіх деталях і бути універсальним за своєю природою. Формування скоріше додає до іміджу декілька штрихів, які підсилюють емоційний вплив на масову свідомість і підкреслюють його позитивні аспекти, жорстко підпорядковуючись вимогам цільової групи виборців. Зрозуміло, що привабливий політик - це той кандидат, в якому виборці вбачають ті якості, які, на їхню думку, є бажаними для лідера. Але, як вважають політологи, громадяни мають останнім часом невиразні уявлення про те, які якості вони хочуть бачити в політичному діячі. Тому часто точкою відліку побудови іміджу політика $є$ інформація про те, які риси в лідері не подобаються людям.

Численні приклади формування іміджу політика свідчать, що його якості особистості повинні бути однозначні, чітко визначені, яскраво виражені і досить постійні. Неодноразово робилися спроби виявити набір рис, якими обов'язково повинен володіти лідер в очах співгромадян. Перш за все, більшість дослідників відзначає, що лідер країни повинен позиціонуватися, як особа активна. Будь-яке різке падіння в популярності, ймовірно, є наслідком бездіяльності політичного діяча перед лицем подій.

Варто зауважити, що політичний лідер часто намагається отримати владу, використовуючи маніпуляційні технології. Проте, як свідчить практика, спроби грубої маніпуляції громадською думкою можуть дати протилежний результат. Особливо нині, коли довіра населення до владних структур і політичних інститутів різко знизилася. Сьогодні, в умовах нестабільної системи цінностей, населення досить часто стикається з так званим «чорним піаром». Це підтверджують і останні президентські перегони, де використовувалась велика кількість «брудних технологій». 
Маніпуляційні технології залишаються дієвими не випадково, оскільки численні дослідження виборчої поведінки доводять, що левова частка електорату підлягає навіюванню, має схильність бути під впливом гіпнотичної дії віри в чудодійні можливості політичних сил. Як писав М. Бердяєв, «... дар людей влади полягає у здібності до навіювання. Владарює той, хто кидає народні маси в гіпнотичний стан... людьми управляють не стільки розсудливі інтереси, скільки пристрасті» (Бердяев, 1995, с. 118). Політик є цементом, який скріплює людей в єдиному пориві, надає сенс інтеграції виборчих орієнтацій у колективний рух.

До того ж, лідер, якщо говорити про агресивну складову проявів його політичної поведінки, - це особистість, яка вміє робити постійний психологічний тиск на людей (принаймні у формі латентного, внутрішньо відчутного виборцями нападу), має рішучість, демонструє метафоричну погрозу, як можливість потенційної дії. При цьому реальної загрози може і не бути, є лише їі імітація. За таких умов, у виборців спрацьовує несвідомий рефлекс підпорядкування інтересам сильного.

Доречно зауважити, що враховуючи ситуацію із відсутністю яскравих особистостей в українському політикумі, певний стан політичної культури i, одночасно наявність великого попиту на оптимально сформований імідж політика, іміджмейкери часто використовують так званий «чорний» $\mathrm{i}$ «сірий» $\mathrm{PR}$ для зниження іміджу конкурента. А серед методів, які використовуються можна виокремити наступні:

- «клапану» - переведення громадської думки з позитиву на негатив. Навіть найсильніші лідери при вмілій атаці на них можуть бути в програші;

- «живої мішені» - перенесення негативу з одного об'єкта на іншій;

- «краплі» - постійна, систематична подача критичного матеріалу поступово створює у споживача інформації відповідний негативний образ;

- «підказки», як спосіб роботи з масовою аудиторією: демонстрація знаків, що підтверджують правильність обраної інтерпретації для конкретної ситуації. Підказка ніби виводить розуміння ситуації на заданий рівень;

- «резонансна технологія»: використання раптового інтересу масової свідомості до чогось. Тут мають на увазі два можливі варіанти розвитку ситуації: коли приходить підтвердження чуткам, що довго 
бродили, або, коли реальна політична кон'юнктура вступає в протиріччя з образом лідера (Корнієнко, Денисюк, 2009).

Для погіршення іміджу конкурента широко використовується й багато інших технологій, у тому числі методи побічного інформаційного впливу, нав'язування критеріїв оцінки, впливу на громадську думку при проведенні соціологічних досліджень, які мають маніпуляційний характер. Нажаль, сьогодні використання брудних технологій сприяє успіху політиків на виборах і тим самим формує в них та їх технологів впевненість в тому, що електорату можна нав' язати будь-яку продукцію, а у населення - неприйняття політики, як сфери діяльності взагалі. На наш погляд, у появі таких технологій винні не тільки «піаристи», але й їх замовники, журналісти, і самі виборці.

Можна зазначити, що у більшості джерел технології, спрямованої на зниження іміджу конкурента, розділяються на технології «партизанської атаки» - анонімного або непрямого нападу на суперника і «фронтальної атаки» - відкритого нападу кандидата на свого суперника.

Так, на думку Т.Е. Грінберг «Партизанська атака» У разі «партизанської атаки» удару по суперникові завдається побічно - сторонніми особами переважно через ЗМІ. Між організаторами атаки i їі виконавцями стоїть цілий ланцюг посередників, деякі з яких використовуються потайно. Тому поняття джерела інформації тут може бути поєднане з поняттям каналу, який і виступає джерелом негативної інформації.

При деструктивній «обробці» джерела можуть використовуватися наступні прийоми: зниження довіри до джерела; напад на джерело; підміни джерела; ототожнення $з$ джерелом інформації.

В перших трьох випадках широко практикується використання чуток. Чутки є окремим специфічним типом комунікації. Основні особливості чуток, що визначають їх використання в антитехнологіях, - принципова анонімність і «не перетинається» тематики чуток $з$ темами засобів масової інформації. Чутки можуть істотно посилити ті або інші латентні стереотипи і представлення електорату. Інформація в чутках анонімна: подається за відсутності вказівки на джерело. Важливою умовою для поширення чуток $є$ відсутність критичного обговорення отримуваної інформації, прийняття ії на віру. Що ж морально-етичних засад технологій, то чутки як раз і $\epsilon$ їх спрощенням. 
Але, слід враховувати, що при підготовці «партизанської атаки» варто пам'ятати про правило «багато - не означає добре». Так, ефективність атаки може понизити: велика кількість тем і епізодів для критики і в результаті загальна непереконливість; надмірні «залякування» виборців і провокації здатні «зіграти» на руку швидше конкурентові, ніж ініціаторові атаки; велика кількість матеріалів здатна перемістити акценти на фігуру конкурента і понизити увагу кандидатові.

Що ж стосується «фронтальної атаки», то вона здійснюється, коли один кандидат атакує іншого публічно або в засобах масової інформації. При грамотному веденні виборчої кампанії необхідність в «фронтальній атаці» виникає украй рідко. Як правило, «фронтальна атака» включає обнародування самим кандидатом неприємних чинників про минуле або про сьогодення суперника (інформація про його ділові махінації, заведену прокуратурою справу, багатократній зраді партійним ідеалам і викраденні партійних грошей і так далі).

Проте, якщо в ході «партизанської атаки» можуть бути використані як реальні факти з життя суперника, так і відверта «чорна» пропаганда, то в «фронтальній» атакувати має сенс, тільки маючи на руках усі документи, що підтверджують звинувачення.

Отже, проведений аналіз іміджу політичного лідера як категорії PR-технології в політиці доводить, що сьогодні використовуються в основному маніпуляційні технології, які залишаються дієвими не випадково, оскільки численні дослідження виборчої поведінки доводять, що основний електорат підпадає під навіюванню, має схильність бути під впливом гіпнотичної дії віри в чудодійні можливості політичних сил.

Застосування «брудних технологій» у політиці сьогодні породило масовий міф про їхню всесильність, а це, в свою чергу, становить пряму загрозу громадянському суспільству, оскільки породжує у громадян стійку ілюзію того, що від їхнього особистого вибору нічого не залежить.

\section{Лimepamypa:}

Бебик, В. М. (1996). Політичний маркетинг і менеджмент. К.: МАУП. Бердяев, Н. А. (1995). Царство Духа и изарство Кесаря. М.: Мысль. Вознесенська, О. (2003). Бестіарні образи ідеальних політиків в уявленні молоді. Соиіально-психологічний вимір демократичних перетворень b Україні. К.: Український центр політичного менеджменту. 
Гринберг, Т. Э. (2005). Политические технологии: ПР и реклама. Учеб. пособие для студентов вузов. М.: Аспект Пресс.

Егорова-Гантман, Е. (1994). Имидж лидера; под. ред. Е. Егорова-Гантман; общество «Знание» России, Центр политического консультирования «Никколо М». М.: Мысль.

Егорова-Гантман, Е. В., Плешаков, К. В., Байбакова, В. Б. (2002). Политическая реклама / Науч. ред. А. А. Бирюков. М.: ЦПК НикколоМедиа.

Зущик, Ю. М. (1999). Фігури. Політичне лідерство в сучасній Украӥні. К.

Корнієнко, В. О., Денисюк, С. Г. (2009). Імідж політичного лідера: проблеми формування та практичної реалізації. Вінниця: УНІВЕРСУМВінниця.

Королько, В. Г. (2002). Основы паблик рилейшнз. М.: Рефл-бук, К.: Ваклер.

Лавренко, О. (2005). Проблеми формування іміджу кандидата в депутати. Трибуна: Всеукраїнський громадсько-політичний і теоретичний журнал Товариства «Знання» України і Спілки журналістів України, №7/8, 24-25.

Макаренко, С. А. (2003). Аналітика. Експертиза. Прогнозування. К.: Науково-видавничий центр «Наша культура і наука».

Миліневський, М. (1997). Імідж політичних партій: Визначення та структура поняття. Проблеми політичної психологї. Київ, 340-342.

Нарижный, Д. Ю., Сурмин, Ю. П. (1999). Проблемы имиджей кандидатов в президенты Украины. Социальные и гуманитарные науки, 2 (2), 66-68.

Політологічний енцииклопедичний словник (2004). / Упор. В. П. Горбатенко; за ред. Ю. С. Шемшученка, В. Д. Бабкіна, В. П. Горбатенка. 2-ге вид., доп. і перероб. К.: Генеза.

Почепцов, Г. (1997). Имидж: от фараонов до президентов. Строительство воображаемых миров в мифе, сказке, анекдоте, рекламе, пропаганде и паблик рилейшинз. К.: АДЕФ-Украина.

Пушкарева, Г. В. (2002). Политический менеджмент. М.: Дело.

Современные тенденции развития символического пространства политики и кониепт идеологии (2004): Материалы дискуссии. А. И. Соловьев, О. Ю. Малинова, О. В. Гаман-Голутвина, М. В. Ильин, С. Н. Пшизова. ПОЛИС, 4, 28-51. 
Фролов, П. (2002). Психотехнології впливу на виборця: правда і вигадки. Наукові студії із соціальної і політичної психологї, 5 (8), 169-182.

\section{References:}

Beby`k, V. M. (1996). Polity`chny`j markety`ng i menedzhment [Political marketing and management]. Kyiv: MAUP. [in Ukrainian].

Berdyayev, N. A. (1995). Tsarstvo Dukha i tsarstvo Kesarya [The kingdom of the Spirit and the kingdom of Caesar]. Moscow: Mysl. [in Russian].

Egorova-Gantman, E. (1994). Imidzh lidera; pod. red. E. Egorova-Gantman; obshchestvo «Znaniye» Rossii. Tsentr politicheskogo konsultirovaniya «Nikkolo M» [Image of a leader; ed. by E. Egorova-Gantman; society "Knowledge" of Russia, Center for Political Consulting "Niccolo M"]. Moscow: Mysl. [in Russian].

Egorova-Gantman, E. V., Pleshakov K. V., Baybakova, V. B. (2002). Politicheskaya reklama [Political Advertising] Nauch. red. A. A. Biryukov. Moscow: TsPK Nikkolo-Media. [in Russian].

Frolov, P. (2002). Psy`xotexnologiyi vply`vu na vy`borcya: pravda i vy`gadky` [Voter Psychotechnology: Truth and Inventions]. Naukovi studiyi iz social noyi i polity 'chnoyi psy xologiyi [Scientific Studies in Social and Political Psychology], 5 (8), 169-182. [in Ukrainian].

Grinberg, T. E. (2005). Politicheskiye tekhnologii: PR i reklama. Ucheb. posobiye dlya studentov vuzov [Political technologies: PR and advertising. Textbook manual for university students]. Moscow: Aspekt Press. [in Russian].

Korniyenko, V. O., Deny`syuk, S. G. (2009). Imidzh polity `hnogo lidera: problemy formuvannya ta prakty chnoyi realizaciyi [The image of a political leader: problems of formation and practical implementation]. Vinnytsia: UNIVERSUM-Vinny`cya. [in Ukrainian].

Korolko, V. G. (2002). Osnovy pablik rileyshnz [The basics of public relations]. Moscow: Refl-buk. Kyiv: Vakler. [in Russian].

Lavrenko, O. (2005). Problemy` formuvannya imidzhu kandy`data $\mathrm{v}$ deputaty [Problems of forming the image of a candidate for deputy]. Try buna: Vseukrayins `ky j gromads`ko-polity`chny`j i teorety chny j zhurnal Tovary `stva «Znannya» Ukrayiny`i Spilky`zhurnalistiv Ukrayiny' [Tribune: All-Ukrainian Socio-Political and Theoretical Journal of the Knowledge Society of Ukraine and Union of Journalists of Ukraine], \# 7/8, 24-25. [in Ukrainian]. 
Makarenko, Ye. A. (2003). Anality`ka. Eksperty`za. Prognozuvannya [Analytics. Expertise. Prognostication]. Kyiv: Naukovo-vy`davny`chy`j centr «Nasha kul tura i nauka». [in Ukrainian].

My`linevs`ky`j, M. (1997). Imidzh polity`chny`x partij: Vy`znachennya ta struktura ponyattya [Image of political parties: Definition and structure of the concept]. Problemy polity'chnoyi psy'xologiyi [Problems of political psychology]. Kyiv, 340-342. [in Ukrainian].

Narizhnyy, D. Yu., Surmin, Yu. P. (1999). Problemy imidzhey kandidatov $\mathrm{v}$ prezidenty Ukrainy [Problems of images of candidates for the presidency of Ukraine]. Sotsialnyye i gumanitarnyye nauki [Social and Human Sciences], 2 (2), 66-68. [in Russian].

Pocheptsov, G. (1997). Imidzh: ot faraonov do prezidentov. Stroitelstvo voobrazhayemykh mirov v mife. skazke. anekdote. reklame. propagande i pablik rileyshinz [Image: from pharaohs to presidents. The construction of imaginary worlds in myth, fairy tale, anecdote, advertising, propaganda and public relations]. Kyiv: ADEF-Ukraina. [in Russian].

Politologichny jency klopedy 'chny j slowny`k (2004). / Upor. V. P. Gorbatenko; za red. Yu. S. Shemshuchenka, V. D. Babkina, V. P. Gorbatenka. 2-ge vy`d., dop. i pererob [Political Science Encyclopedic Dictionary (2004). / Emphasis. VP Gorbatenko; in a row. Y.S. Shemshuchenko, V. D. Babkin, V. P. Gorbatenko. 2nd ed., Suppl. and recycling]. Kyiv: G’eneza. [in Ukrainian].

Pushkareva, G. V. (2002). Politicheskiy menedzhment [Political management]. Moscow: Delo. [in Russian].

Sovremennyye tendentsii razvitiya simvolicheskogo prostranstva politiki i kontsept ideologii (2004) [Current Trends in the Development of the Symbolic Space of Politics and the Concept of Ideology]: Materialy diskussii. A. I. Solovyev. O. Yu. Malinova. O. V. Gaman-Golutvina. M. V. Ilin. S. N. Pshizova [Discussion Materials. A.I. Soloviev, O. Yu. Malinova, O. V. Gaman-Golutvina, M.V. Ilyin, S.N. Pshizova]. POLIS [POLIS], 4, 28-51. [in Russian].

Voznesens `ka, O. (2003). Bestiarni obrazy`ideal`ny`x polity`kiv v uyavlenni molodi [Bestiary images of ideal politicians in the imagination of young people]. Social no-psy 'xologichny ’j vy 'mir demokraty 'chny 'x peretvoren ' $v$ Ukrayini [Socio-psychological dimension of democratic transformations in Ukraine]. Kyiv: Ukrayins`ky`j centr polity`chnogo menedzhmentu. [in Ukrainian]. 
Zushhy`k, Yu. M. (1999). Figury`. Polity 'chne liderstvo v suchasnij Ukrayini [Figures. Political leadership in contemporary Ukraine]. Kyiv. [in Ukrainian].

\section{Анотація \\ Милосердна I.М. Імідж політичного лідера як категорія PR-технологї. - Стаття.}

Стаття присвячена комплексному дослідженню іміджу політичного лідера як категорія PR-технології. Обгрунтовується думка, щуо в практичній політології імідж - ие, насамперед, узагальнений образ, щзо складається у пересічних громадян про політичні суб'єкти. Інша справа, що нині його цуілеспрямовано формують іміджмейкери. В статті Виокремлюються та аналізуються такі основні підходи до визначення поняття іміджу політичного лідера: онтологічний, антропологічний, ціннісний та етичний. Також було встановлено, що для сучасної політики цікавим фактом є те, серед особистісних характеристик останнім часом зросла роль ділових i моральних якостей лідера. Серед них найсутmєвіме місие посідають інтелектуальні якості (які часто ототожнюють з освіченістю). Далі, за частотою згадувань, йде чесність політика, хоча вибориі не вимагають від нъого абсолютної чесності. До того ж, лідер повинен також бути добрим ілюдяним, відданим народу. Ідеальний політик повинен досконало володіти ораторським мистецтвом та бути «доступним для розмови із простими ююдьми». Також в статті здіисснється зауваження, щзо політичнии лідер часто намагається отримати владу, використовуючи маніпуляиійні технології. Встановлено, щзо маніпуляційні технології залишаються дієвими не випадково, оскільки численні дослідження виборчої поведінки доводять, що більша частина електорат підлягає навіюванню, має схильність бути під впливом гіпнотичної дї̈ віри в чудодійні можливості політичних сил. В статті зазначається, що в українському політикумі, при формуванні іміджу політика, іміджмейкери часто використовують так званий «чорний» $i$ «сірий» PR дяя зниження іміджу конкурента. А серед методів, які використовуються можна виокремити наступні: «клапану», «живої мімені», «краплі», «підказки», «резонансна технологія».

Ключові слова: імідж, політичний лідер, PR, політичні технології, політичне маніпулювання. 